\title{
A New Approach to the Household Register of Lelang (樂浪) Commandery*
}

Dae-Jae Park**

\section{Introduction}

The household register of Lelang Commandery, which was first revealed in North Korea in 2006, were originally three wooden tablets discovered in the wooden-chambered tomb (no. 364) located in Chŏngbaektong, Pyŏngyang in the early 1990s, and entitled "the record of the increase and decrease in the number of households in Lelang Commandery by county in the fourth year of Chuyuan." The register contains detailed records of the number of households in 25 counties of Lelang Commandery in $45 \mathrm{BCE}$ as well as the increase and decrease in the number of households compared to the previous year.

For many years, the existence of the household register of Lelang Commandery had been unknown to the world. It only came to be known to the world through a statistical table, titled "the [missing two characters] of the increase and decrease in the number of households in Lelang Commandery by county in the fourth year of Chuyuan (45 BCE)" in the 2006 thesis and book written by a North Korean historian named Son

* This work was supported by the Korea Research Foundation Grant funded by the Korean Government (MEST) (NRF-2007-361-AL0013)

** Professor, Department of Korean History, Korea University, Seoul, South Korea 
Yŏngjong. ${ }^{1}$ Then, in July 2008, Son revised some of the numbers on the household register, ${ }^{2}$ and also made photographs of the wooden tablets public for the first time. ${ }^{3}$

Figure 1. A photograph of the household registers of Lelang Commandery

\section{락랑유적에서 나온 목간}

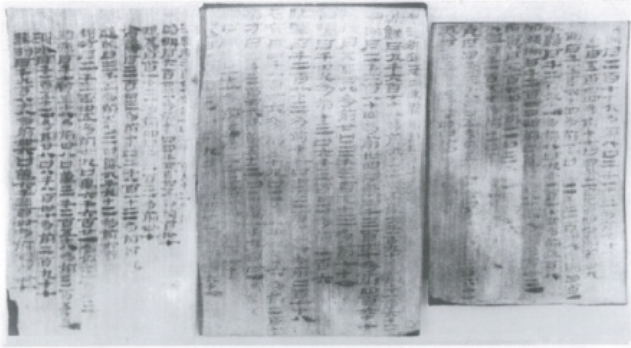

1 Son Yŏngjong, "Rangnanggun Nambujiyŏk (Huŭi Taebanggun Chiyŏk)ŭi Wich'i: 'Rangnanggun Ch'owŏn 4nyŏn Hyŏnbyŏl Hogudaso $\square \square$ ' T'onggyejaryorŭl Chungsimurro [The Location of the Southern Region of Lelang Commandery (later, the Region of Daifeng Commandery): Focusing on the Statistical Source of the Record of the Increase and Decrease in the Number of Households in Lelang Commandery by County in the Fourth Year of Chuyuan]," Ryǒksagwahak (Historical Science) 198 (2006): 30-3; Son Yŏngjong, "Ryodongjibang Chŏnhan Kunhyŏndŭrŭi Wich'iwa Kŭ Huŭi Pyŏnch'ŏn 1 (The locations of Former Han counties in Liaodong and changes afterwards 1)," Ryŏksagwahak (Historical Science) 199 (2006): 49-52; Son Yŏngjong, Chosŏndandaesa: Koguryŏsa 1 (History of Korea: History of Koguryŏ 1) (Pyongyang: Kwahakpaekkwasajŏnch'ulp'ansa, 2006), 118-20.

2 Son Yŏngjong, Chosŏndandaesa: Koguryŏsa 5 (History of Korea: History of Koguryŏ 5) (Pyongyang: Kwahakpaekkwasajŏnch'ulp'ansa, 2008), 206.

3 One black-and-white picture (Figure 1) was published with the caption "Wooden tablet discovered from the Lelang ruins" on the last page of the fourth issue of Chosŏn'gogoyón'gu (Chosŏn archaeology studies) in 2008. The tablet in the center is the first part; the one on the left is the second; and the one on the right is the third part of the household register. 
The existence of the household register became known in the South Korean academic community in $2007,{ }^{4}$ and since then scholars of ancient Korean and Chinese histories have continued to study the register. ${ }^{5}$ Along with the Han dynasty wooden tablets from Juyan (居延漢簡) and Qin dynasty wooden tablets from Liye (里耶秦簡), the household registers of Lelang Commandery is considered to be an important source that provide information on the governing system of the Qin and Han dynasties in the frontier region. Due to the large ethnic population in the frontier regions, previous studies tend to focus on the limitations or the dualistic structure of the regional governing system in Han China concerning the commanderies established in the frontier regions, such as Lelang Commandery, unlike the interior provinces established within the core territories of China. ${ }^{6}$

4 Yun Yong-gu, "Saero Palgyŏndoen Nangnang Mokkan: Nangnanggun Ch'owŏnsanyŏn Hyŏnbyŏrhogubu (Newly Discovered Wooden Tablets from Lelang: The Household Register of Lelang Commandery by county in the fourth year of Chuyuan)," Han'gukkotaesayŏn'gu (The Journal of Ancient Korean History) 46 (2007).

5 Kim Byung-joon, 'Nangnanggun Ch'ogiŭi P'yŏnhogwajŏnggwa 'Hohanch'obyŏl': 'Nangnanggun Ch'owŏnsanyŏn Hyŏnbyŏrhokudaso $\square \square$ ' Mokkanŭl Tansŏro (The process of household registration in the early years of Lelang Commandery and the 'divide and rule' policy toward $\mathrm{Hu}$ and Han: using the wooden tablets on the increase and decrease of the number of households in Lelang Comandery by County in the fourth year of Chuyuan)," Mokkan'gwa Munja (Wooden Documents and Inscriptions Studies) 1 (2008); Yun Yong-gu, "P'yŏngyangch'ult'o 'Nangnanggun Ch'owŏnsanyŏn Hyŏnbyŏrhogubu' Yŏn'gu (The Household Register of Lelang Commandery by county in the fourth year of Chuyuan excavated from Pyŏngyang)," Mokkan'gwa Munja (Wooden Documents and Inscriptions Studies) 3 (2009); Kwon Ojung et al., Nangnanggun Hogubu Yŏn'gu (Studies on the Household Register of Lelang Commandery) (Seoul: Tongbugayŏksajaedan, 2010).

6 Kim Han Kyu, "Handae Pyŏn'gunch'ejeŭi Kujojŏk Sŏnggyŏk (The Structural Nature of the Frontier Commandery System)," in Kodaejunggukchŏksegyejil ssŏyŏn'gu (A Study on the Ancient Chinese World Order) (Seoul: Iljogak, 1982); Kwon Ojung, Nangnanggun Yŏn'gu: Chungguk Kodaebyŏn'gune Taehan Saryejŏk Kŏmt'o (A Study on Lelang Commandery: Review of a Case of an Ancient Fron- 
Recently, however, with the emergence of the household register of Lelang Commandery, the position that the same governing system was implemented in both Lelang Commandery and the interior provinces has begun to gain support. ${ }^{7}$ With the discovery of the household register, scholars have been able to learn that the central government had a detailed understanding of the number of households in Lelang, and that such detailed records could only be created with an established administrative system based on official written documents and laws. The population statistics by county as seen on the household register of Lelang Commandery were part of the Han dynasty's system of submitted accounts (C. shangji, 上計), in which officials reported details about households and the lands of each region to the central government. In the commanderies of the Han dynasty, these accounts were submitted every year in the fall/winter, and the newly released household register contained an organized list of the total number of households in the 25 counties of Lelang Commandery and the changes compared to the previous year.

There are two different perspectives on examining the ruling system of the inner provinces and frontier commanderies: the centralist theory and the dualist theory. The centralist theory refers to the understanding that in the frontiers, as in the interior provinces, commanderies and their counties were governed based on a system of official documents and laws, as de-

tier Commander) (Seoul: Iljogak, 1992); Kwon Ojung, "Handae Pyŏn'gunŭi Pudowi (Commandants of frontier commanderies in the Han dynasty)," Tongyangsahagyŏn'gu (A Study of the History of Asia) 88 (2004).

7 Kim Byung-joon, “Chinhanjegugŭi Pyŏn'gyŏng Iminjok Chibaewa Pudowi (Commandants and the rule over ethnic groups in the frontier regions of the JinHan dynasties," in Chŏnt'ongsidae Tongasiaŭi Oegyowa Pyŏn'gyŏnggigu (Foreign Affairs and Institutions in the Frontier Regions of East Asia in the Ancient Times), ed. Tongbugayŏksajaedan (Seoul: Tongbugayŏksajaedan, 2013); Kim Byung-joon, "Nangnanggun Tongbudowi Chiyŏk Pyŏnhyŏn'gwa Kunhyŏnjibae (Frontier counties in the Commandant of the Eastern Section region of Lelang Commandery and the Governing of Counties and Commanderies)," Han'gukkotaesayŏn'gu (The Journal of Ancient Korean History) 78 (2015). 
duced from the excavated wooden tablets, such as the household register of Lelang Commandery, and that Lelang was no exception.

The particular point of difference in the centralist and dualist theories is the opinion on the central government's ruling system over the last seven counties of Yŏngdong, starting with Tongi county (東暆縣), inscribed on the household register of Lelang Commandery. Scholars with the dualistic perspective have argued that the central government's ruling system over the residents of the frontier regions, including the seven Yŏngdong counties, was not realized properly, unlike in the central regions of Lelang Commandery, since the number of households in the frontiers was considerably fewer than those in the central regions. ${ }^{8}$ In addition, based on the comparison of the population statistics in the household register of Lelang Commandery and the statistics in the "Treatise on Geography" in the Book of Han (漢書 地理志) and the “Treatise on Administrative Geography” in the Book of Later Han (後漢書 郡國志), dualist scholars have asserted that a huge decline in the number of people per household occurred due to the weakening of the Lelang Commandery at the time. In this way, scholars with the dualist perspective understand that the central government's ruling system was unable to be fully implemented in Lelang Commandery due to the indigenous forces in the region and thus fell into a decline. ${ }^{9}$

On the other hand, centralist scholars emphasize that the same ruling system was instituted in both the central counties of Lelang Commandery and the frontier counties of Yŏngdong, based on the record of Tongokchŏ (東沃沮) in the "Records of Eastern Barbarians" from The Records of the

8 Lee Seongje, 'Nangnangŭi Kunhyŏn Chaep'yŏn'gwa Ye (The Reorganization of Counties and Commanderies in Lelang and the Ye people," in Nangnanggun Hogubu Yŏn'gu (Studies on the Household Register of Lelang Commandery), Kwon Ojung et al. (Seoul: Tongbugayŏksajaedan, 2010), 234.

9 Kwon Ojung, "Nangnanggun Yŏn'guŭi Hyŏnhwanggwa Kwaje (Trends and Challenges of Research on Lelang Commandery)," in Nangnanggun Hogubu Yŏn'gu (Studies on the Household Register of Lelang Commandery), Kwon Ojung et al. (Seoul: Tongbugayǒksajaedan, 2010), 28-50. 
Three Kingdoms (San Guo Zhi, 三國志), which states that there were offices of merit (功曹), registrar (主簿), and ministries (諸曹) in Pullae (不 耐), one of the seven Yŏngdong counties, as well as the record of a county court in Qianling, Dongting Commandery, located in the southern frontier of Qin China, found in the Qin dynasty wooden tablets from Liye. ${ }^{10}$

In particular, the issue at the heart of the division between these two theories is the nature of the commandant headquarters of the Eastern Section (東部都尉) of Lelang Commandery in relation to the seven Yŏngdong counties. While the dualists believe that the Commandants were special institutions installed in the frontier to rule over the people of different ethnicities and controlled both the military and civilians, the centralists understand that the commandant headquarters in the frontier regions and the central regions were military facilities that were in charge of military affairs and the safety of the areas under their control.

So far, both sides have used the household register of Lelang Commandery as evidence for their theories. However, a closer look at the household register reveals the points where the two perspectives collide. Immediately after the household register of Lelang Commandery became known to the world, I suspected the meaning of the term "kiho" (其戶), found at the end of the household register, would be the key to understanding the commanderies and commandant headquarters. Therefore, in this paper, I would like to introduce the household register of Lelang Commandery to the European and American academic communities, and at the same time explore the key issues in the debate surrounding the register.

10 Kim Byung-joon, "Nangnanggun Tongbudowi Chiyŏk Pyŏnhyŏn'gwa Kunhyŏnjibae," 158. 


\section{Household Statistics and "Kiho" in the Household Register of Lelang Commandery}

The "fourth year of Chuyuan" in the title of the household register of Lelang Commandery refers to the fourth year in the reign of Emperor Yuan of the Han dynasty (45 BCE). Therefore, the household register is a record of the statistics of the population of Lelang Commandery from 47 to 48 years earlier than the household statistics found in the "Treatise on Geography" of the Book of Han, which contains information from the second year of Yuanshi during the reign of Emperor Ping of Han (2 CE). Below is a comparison of the household statistics of 25 counties in Lelang Commandery found in the household register of Lelang Commandery and in the "Treatise on Geography" of the Book of Han:"

Table 1. Statistics of Households in Lelang by Year

\begin{tabular}{c|c|c|c|c|c}
\hline Year & $\begin{array}{c}\text { Number } \\
\text { of house- } \\
\text { holds }\end{array}$ & $\begin{array}{c}\text { Number } \\
\text { of resi- } \\
\text { dents }\end{array}$ & $\begin{array}{c}\text { Number of resi- } \\
\text { dents per house- } \\
\text { hold }\end{array}$ & $\begin{array}{c}\text { Rate of increase } \\
\text { (households/ } \\
\text { residents) }\end{array}$ & Source \\
\hline $\begin{array}{c}\text { 3rd year of } \\
\text { Chuyuan } \\
\text { (46 BCE) }\end{array}$ & 43,261 & 277,317 & 6.41 & & $\begin{array}{c}\text { Household } \\
\text { register of Lelang } \\
\text { Commandery }\end{array}$ \\
\hline $\begin{array}{c}4 \text { th year of } \\
\text { Chuyuan } \\
(45 \text { BCE) }\end{array}$ & 43,845 & 285,261 & 6.50 & $0.63 / 2.82$ & $\begin{array}{c}\text { Hogister of Lelang } \\
\text { Commandery }\end{array}$ \\
\hline $\begin{array}{c}\text { 2nd year of } \\
\text { Yuanshi } \\
(2 \text { CE) }\end{array}$ & 62,812 & 406,748 & 6.48 & $0.79 / 0.76$ & $\begin{array}{c}\text { Geography," } \\
\text { Gook of Han }\end{array}$ \\
\hline
\end{tabular}

11 Table 1 is based on "The average rate of increase of households per year in Lelang Commandery of Former Han" in Yun Yong-gu, "Nangnanggun Ch'ogiŭi Kunhyŏnjibaewa Hogu P'aak (The Rule over Commanderies and Counties and Household Census in the Early Years of Lelang Commandery)," in Nangnanggun Hogubu Yŏn'gu (Studies on the Household Register of Lelang Commandery), Kwon Ojung et al. (Seoul: Tongbugayŏksajaedan, 2010), 197. 
The following is a table of Lelang Commandery's household statistics by county, including compiling the information on the inscriptions of the household register of Lelang Commandery, deciphered by North Korea's Son Yŏngjong who first introduced the register, and South Korea's Yun Yong-gu: ${ }^{12}$

Table 2. Statistics of Households by County Recorded in the Household Register of Lelang Commandery

\begin{tabular}{|c|c|c|c|c|c|c|}
\hline \multirow{2}{*}{ No. } & \multirow{2}{*}{$\begin{array}{c}\text { Name of } \\
\text { county (縣名) }\end{array}$} & \multicolumn{2}{|c|}{ Households } & \multicolumn{2}{|c|}{ Residents } & \multirow{2}{*}{ Notes } \\
\hline & & Count & Variations & Count & $\begin{array}{l}\text { Varia- } \\
\text { tions }\end{array}$ & \\
\hline 1 & $\begin{array}{c}\text { Chosŏn } \\
\text { (朝鮮) }\end{array}$ & 9,678 & +93 & 56,890 & $+1,862$ & \multirow{9}{*}{$\begin{array}{l}\text { Wooden } \\
\text { tablet (1) }\end{array}$} \\
\hline 2 & $\begin{array}{l}\text { Namgam } \\
\text { (訊邯) }\end{array}$ & 2,284 & +34 & 14,347 & +467 & \\
\hline 3 & $\begin{array}{l}\text { Chŭngji } \\
\text { (增地) }\end{array}$ & 548 & +20 & 3,353 & +71 & \\
\hline 4 & $\begin{array}{l}\text { Chŏmje } \\
\text { (黏蟬) }\end{array}$ & $\begin{array}{c}1,039 \\
(1,049)\end{array}$ & +13 & 6,332 & +206 & \\
\hline 5 & $\begin{array}{l}\text { Samang } \\
\text { (駟望) }\end{array}$ & $\begin{array}{c}1,283 \\
(1,213)\end{array}$ & +11 & 7,391 & +278 & \\
\hline 6 & $\begin{array}{l}\text { Tunyu } \\
\text { (屯有) }\end{array}$ & $\begin{array}{c}4,826 \\
(4,846)\end{array}$ & +59 & 21,906 & +273 & \\
\hline 7 & $\begin{array}{l}\text { Taebang } \\
\text { (帶方) }\end{array}$ & 4,346 & +53 & $\begin{array}{c}28,941 \\
(29,941)\end{array}$ & +574 & \\
\hline 8 & $\begin{array}{l}\text { Yŏrgu } \\
\text { (列口) }\end{array}$ & 817 & +15 & 5,241 & +170 & \\
\hline 9 & $\begin{array}{l}\text { Changjam } \\
\text { (長岑) }\end{array}$ & 683 & +9 & $\begin{array}{c}4,932 \\
(4,942)\end{array}$ & +161 & \\
\hline 10 & $\begin{array}{l}\text { Haemyŏng } \\
\text { (海冥) }\end{array}$ & $\begin{array}{c}338 \\
(348)\end{array}$ & +7 & 2,492 & +91 & \multirow{2}{*}{$\begin{array}{l}\text { Wooden } \\
\text { tablet (2) }\end{array}$} \\
\hline 11 & $\begin{array}{c}\text { Somyŏng } \\
\text { (昭明) }\end{array}$ & 643 & +10 & 4,435 & +137 & \\
\hline
\end{tabular}

12 In Table 2, the numbers in parentheses are the results of Son Yŏngjong's reading of the inscriptions. 


\begin{tabular}{|c|c|c|c|c|c|c|}
\hline 12 & $\begin{array}{l}\text { Chehae } \\
\text { (提奚) }\end{array}$ & 173 & +4 & 1,303 & +37 & \multirow{7}{*}{$\begin{array}{l}\text { Wooden } \\
\text { tablet (2) }\end{array}$} \\
\hline 13 & $\begin{array}{l}\text { Hamja } \\
\text { (含資) }\end{array}$ & 343 & +10 & 2,813 & +109 & \\
\hline 14 & $\begin{array}{l}\text { Susŏng } \\
\text { (遂成) }\end{array}$ & 3,005 & +53 & 19,092 & +630 & \\
\hline 15 & $\begin{array}{l}\text { Nubang } \\
\text { (鏤方) }\end{array}$ & 2,335 & +39 & 16,621 & +343 & \\
\hline 16 & $\begin{array}{c}\text { Honmi } \\
\text { (渾彌) }\end{array}$ & 1,758 & +38 & 13,258 & +355 & \\
\hline 17 & $\begin{array}{l}\text { P'aesu } \\
\text { (浿水) }\end{array}$ & 1,152 & +28 & 8,837 & +297 & \\
\hline 18 & $\begin{array}{l}\text { T'anyŏl } \\
\text { (䓀列) }\end{array}$ & 1,988 & +46 & $\begin{array}{c}16,330 \\
(16,340)\end{array}$ & +537 & \\
\hline 19 & $\begin{array}{l}\text { Tongi } \\
\text { (東暆) }\end{array}$ & 279 & +8 & 2,013 & +61 & \multirow{9}{*}{$\begin{array}{l}\text { Wooden } \\
\text { tablet (3) }\end{array}$} \\
\hline 20 & $\begin{array}{c}\text { Chamt'ae } \\
\text { (䖯台) }\end{array}$ & 544 & +17 & 4,154 & +139 & \\
\hline 21 & $\begin{array}{c}\text { Puri } \\
\text { (不而) }\end{array}$ & 1,564 & +5 & 12,348 & +401 & \\
\hline 22 & $\begin{array}{l}\text { Hwaryŏ } \\
\text { (華麗) }\end{array}$ & 1,291 & +8 & 9,114 & +308 & \\
\hline 23 & $\begin{array}{l}\text { Sadumae } \\
\text { (邪頭昧) }\end{array}$ & 1,244 & 0 & 10,285 & +343 & \\
\hline 24 & $\begin{array}{c}\text { Chŏnmak } \\
\text { (前莫) }\end{array}$ & $\begin{array}{c}534 \\
(544)\end{array}$ & +2 & 3,002 & +36 & \\
\hline 25 & $\begin{array}{c}\text { Pujo } \\
\text { (夫租) }\end{array}$ & 1,150 & +2 & $\begin{array}{l}10, \square 76 \\
(5,111)\end{array}$ & $\begin{array}{l}+\square 8 \\
(+8)\end{array}$ & \\
\hline \multicolumn{2}{|c|}{ • Pŏmho (凡戶) } & $\begin{array}{c}43,845 \\
(43,825)\end{array}$ & +584 & $\begin{array}{c}28 \square, 261 \\
(280,561)^{13} \\
\end{array}$ & · & \\
\hline \multicolumn{2}{|c|}{ Kiho (其戶) } & $37, \square 34$ & $\cdot$ & 242, $\square \square \square$ & $?$ & \\
\hline
\end{tabular}

13 In 2006, Son Yŏngjong first deciphered the number of residents in pŏm (凡) households as "281,261." (Son Yŏngjong, Chosŏndandaesa: Koguryǒsa 1, 120) Then in 2008, he revised the total number of residents of the first six households up to and including the sixth Taebang County to "110,219" and the number of residents of households in the 17th P'aesu County to "8,837," and therefore the total number of residents in pŏm households was revised to "280,561." Son Yŏngjong, Chosŏndandaesa: Koguryŏsa 5, 206. 
In the household register of Lelang Commandery, I would like to examine the last two items noted in the above table: pŏmho (凡戶) and kiho (其戶). Pŏmho (凡戶) denotes the sum of all households and residents in Lelang Commandery, and this term appears in the household register of commanderies in the Han dynasty. However, the meaning of the term kiho (其戶) is not clear in the register.

Son Yŏngjong, who first introduced the household register of Lelang Commandery, read kiho (其戶) as konho (坤戶), and deduced that the term referred to the indigenous population, different from the Han Chinese (漢 人). He explained that "the number of konho referred to the number of chiho (地戶), or in other words the number of t'oho (土戶), meaning indigenous population. In the "Story of Wanggyŏl" in volume 76 of the Book of Later Han, Wangjo, the leader of a rebellion that occurred around $20 \mathrm{CE}$, was referred to as "t'oin (土人)," which was recognized as a term that distinguished the indigenous people of the land from the people of Han. $^{14}$

In line with this theory, Son further asserted that only about 40,000 Han Chinese resided in Lelang Commandery, which accounted for about 14 percent of the total numbering over 280,000 residents, while the indigenous population accounted for about 86 percent of the total population. In addition, he argued that the seven counties, from the seventh Taebang county to the 13th Hamja county, were the seven counties that belonged to Daifeng Commandery, which had been established by Gongsun Kang in 204 in the region south of Lelang Commandery. This area was understood to be the area under the control of the commandant headquarters of the Southern Section (南部都尉府), which was established around Somyŏng county, in Former Han. Son further grouped the last seven counties, from the 19th Tongi county to the 25th Pujo county, into the seven Yŏngdong counties, under the control of the commandant headquarters of the Eastern Section.

In the South Korean academic community, there have been achieve-

14 Son Yŏngjong, Chosŏndandaesa: Koguryŏsa 1, 120-1. 
ments, such as the re-deciphering of konho (坤戶) as kiho (其戶), but the nature of the term has not been explained in detail. Additionally, the general perspective of the academic community is to see kiho as the indigenous population of Kochosŏn, or t'oho (土戶), similar to Son's argument. $^{15}$

In the household register wooden tablets of the Han dynasty, kiho refers to a certain number of households, and the specific description of kiho is recorded next to the number of ki households. In general, on inscribed wooden tablets of the Han dynasty, the number of $k i$ (其) households are recorded after the number of pŏm (凡) households, followed by specific descriptions, such as $p u$ (復), $s a$ (死), chijung (泜中), kasa (可事), and hoengnyu (獲流). However, it is difficult to decipher the characters that follow the number of $k i$ households on the household register of Lelang Commandery. From the traces of ink writings at the end of the register, it is highly likely that the specific descriptions of kiho are simple, two or three characters. ${ }^{16}$

On household register wooden tablets of the Han dynasty, the character $k i$ is used to mean "among them" in a list of items in ledgers. ${ }^{17}$ In the register of Tunghai Commandery of the Han dynasty (Han dynasty wooden tablets from Yinwan, 尹灣漢簡), which was excavated in 1993 from

15 Kwon Ojung, "Nangnanggun Wangjojŏnggwŏn Sŏngnibŭi Kukchejŏk Hwan'gyŏng (The International Environment Surrounding the Dynastic Government of Lelang Commandery)," Yoksa Hakbo 196 (2007); Kwon Ojung, "Nangnanggun Yŏn'guŭi Hyŏnhwanggwa Kwaje”; Kim Byung-joon, "Nangnanggun Ch'ogiŭi P'yŏnhogwajŏnggwa 'Hohanch'obyŏl'; Kim Jung-Bae, "Kojosŏnŭi Ch'ingwanggwa In'gu Munje (The Claiming of Kingship and the Issue of Population in Kojosŏn)," in Kojosŏne Taehan Saeroun Haesŏk (A New Interpretation of Kojosŏn) (Seoul: Koryŏdaehakkyo Minjongmunhwayŏn'guwŏn, 2010).

16 Yun Yong-gu, "Nangnanggun Ch'ogiŭi Kunhyŏnjibaewa Hogu P'aak," 199.

17 京都大學人文科學研究所簡牘研究班 (Kyoto University Institute for Research in Humanities, Bamboo and Wooden Tablets Research Team), 漢簡語彙:中國古代木 簡辭典 (Wooden tablets from the Han dynasty: a dictionary of wooden strips from ancient China) (Tokyo: Iwanami Shoten, 2015), 73. 
Yinwancun, Lianyungang in China's Jiangsu Province, there were 11,662 kiho, which accounted for about three percent of 266,290 pŏm households. The characters “獲流” were found under the $k i$ households, meaning that they were migrants who had been brought together to the region. ${ }^{18}$ Likewise, it is certain that kiho in the household register of Lelang Commandery refers to certain households, which account for 86 percent of all households, but it is impossible to decipher the description of the $k i$ households. Therefore, it would be unreasonable to assume that kiho simply refers to "indigenous people."

The reason Son Yŏngjong read kiho as konho was because the character “其” was a variant character. The character “其” on inscribed wooden tablets and steles from the Qin and Han dynasties is often confused with other ancient characters as on ancient bronze objects (or characters written in the style of calligraphy often found on seals). The top part of the character "其" is sometimes written like an " $\mathrm{X}$ " or includes an extra vertical stroke. ${ }^{19}$ The wooden tablets from Liye, recently excavated from the ancient ruins of Longshan County in Hunan Province, China, were marked with the following ink inscription: “片百十一人其廿八死亡” (Figure 2). ${ }^{20}$ The inscription was a record of the death of 28 people from a total of 151 people, where "death" was written as a specific description of $k i$. This showed that the terms $k i$ and porm had already been in use since before the founding of the Qin dynasty.

18 Yun Jae-Seug, "Chinhandae Hogubuwa Kŭ Unyong (Household Registers from Qin and Han Dynasties and Their Management)," in Nangnanggun Hogubu Yŏn'gu (Studies on the Household Register of Lelang Commandery), Kwon Ojung et al. (Seoul: Tongbugayŏksajaedan, 2010), 97.

19 Zang Kehe and Gui Rui, 中國異體字大系: 隷書篇 (An Overview of Variant Characters in Chinese: Lishu Calligraphy) (Shanghai: Shanghai shu hua she, 2010), 57.

20 Zhang Chunlong, Song Shaohua and Zheng Shubin ed. Hu Xiang Jian Du Shu Fa Xuan $J i$ (Collection of Calligraphy on Bamboo and Wooden Tablets from Huxiang) (Changsha: Hunan mei shu chu ban she, 2012), 22. 
According to the section on Ye (濊) from the "Records of Eastern Barbarians" in the Records of the Three Kingdoms, "huren (胡人, barbarians)" and "the people of Han" began to be distinguished since Emperor Wu of Han destroyed (Ko) Chosŏn and established four commanderies. The existence of these records led scholars to believe that there was an administrative distinction between the huren and the people of Han at the time the household register was compiled in Lelang Commandery. ${ }^{21}$ In addition, the fact that Wang Diao from Lelang Commandery in the Records of the Three Kingdoms was described as "t'oin (土人)" also hinted at the possibility that the indigenous population had been distinguished from the rest of the population for administrative purposes in Lelang Commandery. ${ }^{22}$ Other records have also

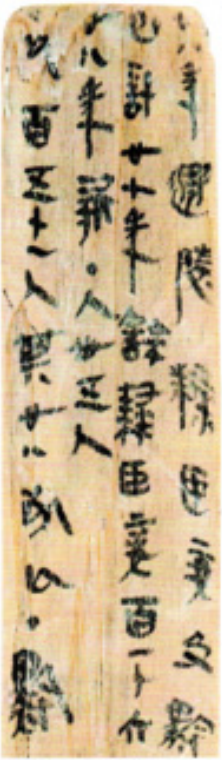

Figure 2. Qin dynasty wooden tablets from Liye shown that there were notations that distinguished the people of Qin or Han from other ethnic people during the Qin and Han dynasties. On the wooden tablets of a family register from Liye, the people of Yuanchu were marked with the character “荊 (hyŏng), " distinguished from the people of Qin; and tribe names of the Qiang people were specified on the wooden tablets from Dunhuang. ${ }^{23}$

21 Kim Byung-joon, "Nangnanggun Ch'ogiŭi P'yŏnhogwajŏnggwa 'Hohanch'obyŏl'," 182-3.

22 Lee Sung-Kyu, "Chungguk Kunhyŏnŭrosouŭi Nangnang (Lelang as a Commander of China)," in Nangnangmunhwayŏn'gu (A Study of Nangnang Culture), Lee Sung-Kyu et al. (Seoul: Tongbugayŏksajaedan, 2006), 32-3.

23 Kim Kyung-Ho, "Chinhansigi Hogumunsŏwa Pyŏn'gyŏng Chibae (Household register documents and the rule over the frontier region in the Qin and Han dynasties)," in Nangnanggun Hogubu Yŏn'gu (Studies on the Household Register of Lelang Commandery), Kwon Ojung et al. (Seoul: Tongbugayŏksajaedan, 2010), 137-8. 
In previous studies, many scholars tend to understand kiho in the household register of Lelang Commandery as a notation for the indigenous population, who were ethnically different from the people of the Han dynasty. However, without further descriptions of kiho, it would be difficult to speculate on the characteristics of the households. Therefore, I would like to examine the nature of the term "kiho (其戶) found on the household register of Lelang Commandery, in relation to the household statistics. About 37,000 households, with a total of over 240,000 residents, were marked as kiho. Coincidentally, the number of households marked as kiho was extremely close to the number of households of 18 counties in Lelang, excluding the last seven counties of Yŏngdong.

Table 3. Statistics of the Total Amount of Households excluding the seven counties of Yŏngdong

\begin{tabular}{l|c|c}
\hline \multicolumn{1}{c|}{ Category } & $\begin{array}{c}\text { Number of } \\
\text { households }\end{array}$ & $\begin{array}{c}\text { Number of resi- } \\
\text { dents }\end{array}$ \\
\hline Number of pŏm households (凡戶口數) (A) & $\begin{array}{c}43,845 \\
(43,825)\end{array}$ & $\begin{array}{c}28 \square, 261 \\
(280,561)\end{array}$ \\
\hline Number of households in the seven Yŏngdong & 6,606 & $5 \square, \square 92$ \\
counties (B) & $(6,616)$ & $(46,027)$ \\
\hline A-B & 37,239 & $23 \square, \square 59$ \\
& $(37,209)$ & $(234,269)$ \\
\hline Number of ki households (其戶口數) & $37, \square 34$ & $242, \square \square \square$ \\
\hline
\end{tabular}

In Table 3, the numbers enclosed by parentheses are statistics that have been calculated based on the inscriptions on the wooden tablets deciphered by Son Yŏngjong. Considering that Son's reading and interpretation of the inscriptions differ from the readings and interpretations of the South Korean academic community as seen in Table 2, it is noteworthy that the total number of households, excluding the seven Yŏngdong counties, calculated from Son's theory as noted in Table 3 is very close to the total number of $k i$ households.

Since the number of residents of Pujo county is uncertain, it is difficult to make an accurate comparison but a relative comparison can be made, since the difference in the number of households calculated by Son and 
the South Korean academic community is small - considering the fact that the deciphering of characters is often imperfect, the difference in the numbers deduced above seems rather trivial. From this perspective, kiho seems to be a notation that distinguished the residents of 18 counties, centered around Chosŏn county, which was the center of Lelang Commandery.

The fact that the number of households in Lelang, excluding the seven Yŏngdong counties, is very similar to the number of kiho households could be an important clue that can help us understand the nature of kiho. This hints at the possibility that there might have been some kind of geographic distinction between the first 18 counties including Chosŏn county and the seven Yŏngdong counties located east of Dandan-Taeryŏng (單單 大嶺, Nangrim Mountains). And it seems that the reason the number of households in 18 central counties and in seven Yŏngdong counties were counted separately is related to the characteristics of the commandant headquarters of the Eastern Section as well.

\section{The Characteristics of the Seven Counties of Yŏngdong and the Commandant of the Eastern Section (東部都尉)}

As mentioned above, the academic community has been divided in terms of the characteristics of the commandant headquarters set up in the frontier regions during the Han dynasty. While the commandants of interior provinces were in charge of aiding the governors ( $t$ 'aesu, 太守) of commanderies and overseeing military duties, commandants in the frontier regions were responsible for overseeing military as well as civilian affairs, with subordinate military units and officials, such as companies (houguan, 候官), heads of platoons (houzhang, 候長), and heads of sections (suizhang, 隧長), as well as other lower level military officials, including sima (司馬) and qianren (千人), in addition to deputy commanders (cheng, 丞) and civil officials (yuanshu，掾屬). According to previous studies, some of the commanderies established in the frontier regions dur- 
ing the early reign of Emperor Wu of Han were only headed by commandants instead of governors, or the commandants were placed along with governors and put in charge of the counties within commanderies. ${ }^{24}$

Commandants were also set up in the manyi (蠻夷, barbarians) region, which was newly incorporated into the military system of the Han dynasty, commanded counties along with governors, and took charge of overseeing both civilian and military affairs. It is also understood that the areas under the control of commandants were levied lower taxes than the central areas in the commanderies, which was an appropriate measure for ethnic groups that were incorporated into the Han dynasty. ${ }^{25}$ Based on these studies, the general perspective on commandants of the frontier regions is that the commandants were not only in charge of the military but also civilian affairs in the counties of the commanderies. ${ }^{26}$

Recently, however, one study offers a different perspective on the commandant headquarters of the commanderies in the frontier regions through an analysis of the wooden tablets from Juyan. According to this study, commandants of the frontier commanderies were not in charge of the counties, as they were organizations specialized in military matters and inspections; for administrative tasks, such as trials, commandants had to request counties to take care of administrative affairs through companies; and counties and the commandant headquarters had a mutually beneficial relationship. ${ }^{27}$ This study limits the scope of commandants as mili-

24 Yan Gengwang, Qin Han Difang Xingzheng Zhidu (The Regional Administrative System in the Qin and Han Dynasties) (Shanghai: Shanghai gu ji chu ban she, 2007), 155-74 (Original Publication 1961)

25 Kamada Shigeo, “郡都尉 (Commandants of Commanderies)," in Shin Kan Seiji Seido no Kenkyu (Research on the Political System in the Qin and Han Dynasties) (Tokyo: Nihon Gakujutsu Shinkōkai, 1962), 318-20.

26 Kwon Ojung, "Handae Pyŏn'gunŭi Pudowi”; Yun Yong-gu, "Nangnanggun Ch'ogiŭi Kunhyŏnjibaewa Hogu P'aak."

27 Noguchi Yu, “前漢邊郡都尉府の職掌と邊郡統治制度 (The Duties of the Office of the Chief Commandant in the Border Regions and the System of Rule of the Border Regions)," Tōyōshii Kenkyü (The Journal of Oriental Research) 71-1 (2012): 
tary organizations that were counterparts to counties, which oversaw civilian affairs. Another recent study also assumes a similar position, asserting that commandants in the frontier regions, just as commandant headquarters in the interior provinces, were only in charge of military and police affairs, and did not engage in civilian affairs. ${ }^{28}$

Scholars with the perspective that commandants only oversaw military affairs and not civilian affairs base their opinion on the following record in the Old Rites of the Han (Han Jiu Yi，漢舊儀):

A. The governors of frontier commanderies patrol the fortifications and beacons with the cavalry and guard against foreign enemies. They have one changshi (aide, 長史) in charge of the army, and one deputy commander (丞) who oversees civilian affairs. Battles are led by changshi (長史). Governors have commandants (部都尉), qianren (千人), sima (司馬), hou (候), and officers of agriculture (農都尉) under them, and none of them oversee civilian affairs or provide guards. ${ }^{29}$

This record, found in the Old Rites of the Han written by Wei Hong during the reign of Emperor Gwangwu of the Later Han, clearly stated that commandants of the frontier commanderies did not have the authority to oversee civilian affairs. Military affairs in the frontier commanderies were also overseen by the governors of the commanderies and adminis-

\section{$22-7$.}

28 Kim Byung-joon, "Nangnanggun Tongbudowi Chiyŏk Pyŏnhyŏn'gwa Kunhyŏnjibae."

29 Wei Hong (衛宏), “邊郡太守各將萬騎 行障塞烽火追虜 置長史一人掌兵馬 丞一人治民 當兵行 長史領 置部都尉·千人·司馬·候·農都尉 皆不治民 不給衛士,” Han Jiu Yi (漢舊儀) Vol. 2, ed. Sun Xingyan (孫星衍) [Zhou Tianyou (周天游), ed. Han Guan Liu Zhong (漢官六種) (Beijing: Zhonghua Shu Ju, 1990), 81]. In the Han Guan Yi (Observances of the Han Bureaucracy, 漢官儀) written by Ying Shao (應劭) during the reign of Emperor Ling of the Later Han, “部都尉” are written as “部尉.” 
tered by changshi (長史). However, there is a contradictory record in the "Records of Eastern Barbarians" in the Records of the Three Kingdoms, stating that the commandant "separately led (別主)" the seven counties of Yŏngdong:

B. In the second year of Yuanfeng (109 BCE). Emperor Wu of Han conquered Chosŏn, killed Ugŏ, the grandson of Man, divided the conquered territory and set up four commanderies, and turned Okchŏsŏng into Xuantu Commandery. After the barbarian invasion, the commandery was relocated to the northwest of Koguryŏ, and is now known as Xuantu gufu (玄菟故府). Later, Okchŏ became part of Lelang. Since the Han territory was extensive and vast, the Commandant of the Eastern Section was set up in the region east of Dandan-Taeryŏng (單單大嶺) and established Pullae as the administrative city to separately rule (別主) the seven Yŏngdong counties. At that time, Okchŏ also became a county. ${ }^{30}$

A statement similar to Record B also appears in the section on Ye in the "Records of Eastern Barbarians" from the Records of the Three Kingdoms: "the area west of Dandan-Taeryŏng was incorporated into Lelang, and the seven counties east of the mountain was ruled (主之) by a commandant, and the Ye (濊) were its residents." This record clarifies that the region west of Nangrim Mountains belonged to Lelang, while the seven counties to the east were governed by the commandant. Yet instead of “別 主," meaning to rule separately, the record indicated that the seven counties were governed using the characters “主之.” The records on Tongokchŏ in the "Book of Eastern Barbarians" from the Book of Later Han indicates that Okchŏ was turned into a county, within the commandant headquarters of the Eastern Section of Lelang. According to the Records of the Three Kingdoms and the Book of Later Han, it seems that the seven counties of Yŏngdong were under the jurisdiction of the commandant

30 San Guo Zhi (三國志) 30, Records of Eastern Barbarians, “Tongokchŏ.” 
headquarters of the Eastern Section, separate from the central regions of Lelang.

Scholars who believe that the commandant was only in charge of military affairs interpret “別主” as duties limited to military affairs. In other words, the record that the commandant headquarters of the Eastern Section "separately ruled" the seven Yŏngdong counties did not mean that the commandant was in charge of the counties' administrative affairs, but that the commandant headquarters of the Eastern Section took charge of military affairs of the seven Yŏngdong counties because the commandant of Lelang commandery was unable to oversee the military affairs of the whole commandery. ${ }^{31}$ In the frontier commanderies, just as in the interior provinces, the commandant headquarters were established directly under the offices of the governors to oversee military and police affairs. Therefore, the establishment of a commandant of a regional section in an area far from the center of the commandery, military and police matters of the regions would have been naturally divided between the commandant of a regional section and the commandant of the central regions.

In the section on Tongokchó in the Records of the Three Kingdoms, records on Lelang and the commandant headquarters of the Eastern Section were parallel, written in juxtaposition. Moreover, the section on Ye in the Records of the Three Kingdoms also distinguished between the two regions, stating that the regions west of Nangrim Mountains belonged to Lelang while the regions east of the Mountains was placed under the rule of the commandant of the Eastern Section. Instead of reading into the meaning of “主," if we take the character at face value, it is natural to understand that the commandant of the Eastern Section governed the seven Yŏngdong counties on its own.

As explained above, the entry in the "Records of Eastern Barbarians" from the Records of the Three Kingdoms and the accounts of commandants in the Old Rites of the Han seem contradictory. Then how should

31 Kim Byung-joon, "Nangnanggun Tongbudowi Chiyŏk Pyŏnhyŏn'gwa Kunhyŏnjibae," 166. 
we understand this contradiction in the historical records? In previous studies, the types of commandants in the frontier commanderies are divided into "eastern/southern regions," where the commandants were in charge of both the military and civilian affairs, and the "western/northern regions," where the commandants were in charge of only the military affairs. Some scholars have also argued that the record in the Old Rites of the Han was a generalization of the characteristic of the western/northern commandants, whose roles were relatively more important, as those regions bordered the territories of the Xiongnu. ${ }^{32}$

This categorization based on the characteristics of the commandants provides an important clue for understanding these seemingly contradictory records of the Records of the Three Kingdoms and the Old Rites of the Han. While most of the previous research attempts to explain the characteristics of the frontier commandant headquarters as though all of the commandant headquarters were the same, it is certainly possible that the roles of the commandants varied depending on their location. It is also related to the possibility that the commandery and county system of the Han dynasty was implemented to different degrees depending on the forces of the ethnic people who shared borders with the frontier commanderies. In particular, it is speculated that the ruling system of the western/northern frontier regions, where fortresses and walls had been built, was different from the ruling system of other peripheral regions.

In addition to the geographical differences, it is important to consider the changes in the characteristics of the commandant headquarters over time. The analysis of the wooden tablets from Juyan discovered in the northern frontier commandery of Zhangye shows that the counties under direct control of commandant headquarters existed in the Juyan region from the Xin dynasty founded by Wang Mang to the reign of Emperor Gwangmu of the Later Han. In the documents issued by the commandant

32 Ichikawa Ninzo, “前漢邊郡都尉考 (Thoughts on the commandants of frontier commanderies of the Former Han)," Rissho Daigaku Kyoyobu Kiyo (Bulletin of the College of Education, Rissho University) 2 (1968): 7-10. 
headquarters in Juyan to a county, guanxian (官縣) is recorded as a county under direct supervision of the commandant, which signaled an important change in the characteristics of the commandant headquarters. Guanxian (官縣) appears in eleven wooden tablettablets from Juyan, among which six are documents that have been issued by the commandant of Juyan to guanxian. $^{33}$

For instance, one is an order of the commandant of Juyan, Zhangye Commandery, in the eighth year of Jianwu (32 CE), issued (謂) to guanxian through (告) the office of agriculture (勸農掾) to prepare for the spring rites to the spirits of the land and grains (EPT 20-4). ${ }^{34}$ As the characters “告” and “謂” are used in official documents to illustrate superior and subordinates, the office of agriculture is considered to be higher up in the hierarchy than guanxian. The commandant of Juyan issued an order through the office of agriculture to guanxian to prepare for the spring rites to the altar of the spirits of the land and grains. Here, it is also noteworthy that the order issued to guanxian was not regarding military matters but about a rite.

In the wooden tablet from the same time period, the commandant of Juyan also issued (謂) an order to guanxian through (告) sima (司馬) and qianren (千人) of subordinate offices to the commandant headquarters to transfer documents (EPF 22-71A). ${ }^{35}$ One of the wooden tablets from the reign of Wang Mang is also a document notifying (謂) guanxian (官縣) of the transfer (移) of jibuqian (計簿錢), which had been sent by the general's office to the governor, to the commandant (EPF 22-173A). ${ }^{36}$ The

33 Kadoya Tsuneko, “漢代居延における軍政系統と縣との關わりについて (The relationship between the military system and counties in Juyan during the Han dynasty)," Shilin 76-1 (1993): 56-62.

34 “建武八年三月己丑朔 張掖居延都尉諶行丞事城騎千人躬告勸農掾禹 謂官縣令以春 祠社稷 今擇吉日如牒 書到令丞循行謹修治社稷令鮮明令丞下當.” (Kadoya, “漢代居 延における軍政系統と縣との關わりについて,” 58)

35 “六月壬申 守張掖居延都尉曠丞崇告司馬千人官 謂官縣 寫移書到如大將軍莫府書律 令.” (Kadoya, “漢代居延における軍政系統と縣との關わりについて,” 59)

36 “...長口口行太守事守丞宏移部都尉 謂官縣大將軍莫府移計簿錢所牒...莫府錄律令” 
character “移," meaning to transfer, is used between offices of the same level, which means the office of the governor and the commandant headquarters were of an equal level, while guanxian was subordinate to the two offices.

In Han dynasty wooden tablets, the character “官 (guan)” sometimes referred to companies (houguan 候官), which were under the supervision of the commandant. Moreover, considering the fact that these documents had been excavated from jiaqu houguan (甲渠候官) in Juyan, “官 (guan)” in “官縣 (guanxian)” seems to refer to “候官 (houguan).” The fact that guanxian received a direct notice from the commandant headquarters means that guanxian was an organization directly under the control of the commandant headquarters. Based on these facts, some scholars believe that guanxian refers to houguan and xian (county, 縣) under direct control of the commandant headquarters and that the commandant headquarters also functioned as a civil administration unit with counties under its direct control. ${ }^{37}$

It is important to note that, among the 11 mentions of guanxian on the wooden tablets from Juyan, there are two records indicating that the governor's office directly issued documents to guanxian (EPT 59-160, EPF 22-65A). In previous studies, these two instances were considered exceptions to the interpretation of guanxian as "houguan (company) and xian (county)," and was thought only to refer to counties. ${ }^{38}$

However, it is difficult to accept the above theory, in which the same term was used to refer to two different things in official documents. Even if it is an exception, the speculation that guanxian refers only to xian does not explain the reason the character “官 (guan)” was added before “縣 (xian)." On the other hand, the hypothesis that guanxian refers to houguan and xian also does not explain the reason the office of the governor issued direct orders to (hou)guan, rather than through the comman-

(Kadoya, “漢代居延における軍政系統と縣との關わりについて,” 60)

37 Kadoya, “漢代居延における軍政系統と縣との關わりについて,” 57.

38 Kadoya, “漢代居延における軍政系統と縣との關わりについて,”61-2. 
dant headquarters, which was in direct control of guan. Therefore, guanxian should not be understood as "guan and xian" but as "xian (county) related to guan (houguan)." The reason guanxian directly received documents from the office of the governor is because of it was fundamentally a county, and guan was attached to xian in order to define and specify that the county was directly related to houguan. In other words, guanxian was a county under the control of both the governor and commandant, and while such counties often received documents through the commandant headquarters, occasionally they also received documents directly from the office of the governor. More research needs to be conducted to investigate the characteristics of guanxian, but it is possible to presume what kind of administrative functions the commandant headquarters of the frontier commanderies performed.

The existence of guanxian, which was under the supervision of the commandant headquarters, was confirmed by the wooden tablets from Juyan. Yet, in terms of time period, they were mentioned from the Xin dynasty founded by Wang Mang to the reign of Emperor Guangwu of the Later Han. As is well known, in the sixth year of Jianwu (30 CE) in the reign of Emperor Guangwu, the commandant headquarters were abolished. ${ }^{39}$ During this time, the commandant headquarters of the Eastern Section of Lelang Commandery was dissolved as well, although not all commandant headquarters of the frontier commanderies were abolished. As seen in the records from the wooden tablets discovered in Juyan, the commandant headquarters in strategically important locations were maintained. Records from the Observances of the Han Bureaucracy (漢官儀) also indicate that although the commandant headquarters were abolished in the sixth year of Jianwu, they were occasionally set up in the frontier commanderies and dependent states (屬國). ${ }^{40}$

39 “是歲初罷郡國都尉官,” Hou Han Shu (Book of Later Han) 1, Records from the reign of Emperor Guangwu.

40 “秦郡有尉一人 典兵禁 備盜賊 景帝更名都尉 建武六年省 惟邊郡往往置都尉及屬國 都尉,” Han Guan Yi (漢官儀) (Zhou Tianyou, ed. Han Guan Liu Zhong, 151) 
Compared to the Former Han, the commandant headquarters in the frontier commanderies and dependent states in the Later Han had a more elevated status and expanded roles. The commandant headquarters of the dependent state of Sichuan was established in the Southwestern Yi area and described to be "like the office of the governor, with four affiliated counties (領四縣如太守)." ${ }^{41}$ Compared to the records in the "Treatise on Geography" from the Book of Han, when the commandant headquarters and dependent states were described as institutions subordinate to the military, the status and functions of the commandant headquarters were elevated and expanded. Commandant headquarters existed to the end of the Later Han, and they were established not only in the frontier commanderies but also in strategically important areas in the interior provinces. As a result, the commandant headquarters in the late Later Han was transformed into a governing institution that handled civilian affairs in the interior provinces, and this transformation in the role of the commandant headquarters continued into the Three Kingdoms period and the Jin dynasty. $^{42}$

The records about commandant headquarters in the "Records of Eastern Barbarians" from the Records of the Three Kingdoms can be understood as a reflection of the evolving characteristics of commandant headquarters in the Three Kingdoms period. According to the Old Rites of the Han and Observances of the Han Bureaucracy, it is highly possible that the commandant headquarters of the northwestern frontier commanderies in the Former Han were organizations originally in charge of solely military and police affairs. The process in which the commandants of the northwestern frontier commanderies were transformed into institutions that oversaw civilian affairs can be understood through the existence of commandant headquarters with guanxian, mentioned in the wooden tablets from Juyan.

Since the Records of the Three Kingdoms indicate that all seven Yŏng-

41 Hou Han Shu (Book of Later Han) 86, Story of Southwesten Barbarians.

42 Kwon Ojung, "Handae Pyŏn'gunŭi Pudowi," 26-8. 
dong counties had the people of Ye as residents, it is possible for scholars to mistake that the commandant headquarters were only installed in the regions occupied by the barbarians and governed the barbarians. However, the commandant headquarters were not only established in the areas occupied by the Manyi but also in other regions. In Juyan, where the commandant headquarters had been established, ethnic Han Chinese who had become civilians in Guandong, China, were residing in communities, and most of the non-ethnic Chinese who were relegated to the Han dynasty were assigned to reside in the dependent states located in the southern region of Zhangye Commandery. ${ }^{43}$ Then in the fourth year of Tianhan (97 BCE), the Zeduyi (䇤都夷) in the southwestern region was incorporated into the Shu Commandery and became the Southern Section of the commandery. In addition, two commandants were established, with one governing the "barbarians" at the frontier while the other governed the Han Chinese. ${ }^{44}$ As evidenced by this record, commandant headquarters were established in regions other than the ones occupied by the Manyi.

The records on the wooden tablets of Juyan indicate that the governor of the commandery oversaw the several Commandants as a military general through changshi in the system of defense organization of Zhangye Commandery in the Former Han. This shows that in term of military affairs of the frontier commanderies, the commandant headquarters were under the direction of the governor of the commandery. ${ }^{45}$ These records remind us that our previous understanding of the commandants was rather distorted in the past.

The fact that the number of households in the seven counties of Yŏngdong appears alongside the other 18 counties in the household register of Lelang Commandery implies that the reach of the Lelang governor's ad-

43 Noguchi Yu, “前漢邊郡都尉府の職掌と邊郡統治制度,” 18.

44 Hou Han Shu (Book of Later Han) 86, Story of Southwesten Barbarians

45 Chen Mengjia, “漢簡所見居延邊塞與防御組織 (Fortresses and defense organizations in the frontier region of Juyan seen from Han dynasty wooden slips)," Kao Gu Xue Bao (Acta Archaeologica Sinica) 1 (1964): 55-86. 
ministrative rule included the region under the commandant headquarters of the Eastern Section. It is important to note that, nevertheless, the household statistics of the central 18 counties of Lelang Commandery were distinguished from the seven Yŏngdong counties by marking them as “kiho (其戶)."

This mark is evidence that there was a distinction between the central region directly governed by the governor of the commandery and the frontier region where the commandant was established. The changes in the number of households located in the central region of the commandery directly governed by the governor were used as sources for evaluating the governor's ability to rule. The total number of households in the central region, excluding the households in the frontier region where the commandant headquarters were established, would have been a great basic resource to assess the civil administrative performance of the governor of the commandery. Excluding the frontier region, where the number of households changed often, the central region was probably the smallest scope of jurisdiction over which the governor had full and direct responsibility.

The point of contact between the centralist and dualist perspectives surrounding the nature of commandants could be found in the distinction between the central region and the Yorngdong region indicated in the household register of Lelang Commandery. It appears that the commandant headquarters, unlike the centralist perspective, did not have a separate civil administrative function, such as assessing the number of households, around the fourth year of Chuyuan, since the governor of the commandery kept count of the households in the seven Yongdong counties along with the households in the counties in the central region.

It is also difficult to assume that county-level civil administration was established in the frontier counties in the Former Han, allowing the governor of the commandery to rule over the whole commandery, simply based on the section on Tongokchŏ from the Records of the Three Kingdoms, since that particular record was about the time period after the commandant headquarters of the Yŏngdong region was abolished in the 
sixth year of Jianwu (30 CE) and counties including Pullae, Hwaryŏ, and Okchŏ became fiefdoms. In the record that indicates, "However, the offices of merit (功曹), registrar (主簿), ministries (諸曹) still remain to date in the fiefdom of Pullae, and these offices were undertaken by the people of Ye," 46 the characters “至今” meaning "to date" refers to the time period when the Records of the Three Kingdoms was compiled in Jin China (280s CE) or the Three Kingdoms period (220-265 CE).

As a result, it is difficult to confirm whether civil administrative institutions such as ministries and offices of merit and registrar were established in Pullae during the Former Han. It is possible that the civil administrative institutions were established in counties after the role of the commandant headquarters was expanded or the commandant headquarters was abolished and the counties became fiefdoms. Therefore it is difficult to assume that the seven Yŏngdong counties, where commandants were established in the Former Han, had been under centralized rule through countylevel administration.

While the governor of the commandery held administrative rule over the frontier region of Lelang Commandery, it seems that the frontier region was governed separately from the central region where the commandant headquarters was not established. In other words, the governor's administrative power inclusively reached the frontier region, but there were differences between the regions where the commandant headquarters was established and the regions without the commandant headquarters. Due to this multi-layered structure of the commandery, it seems that the household register of Lelang Commandery distinguishes between the central Lelang region and the Yŏngdong region, where the commandant headquarters of the Eastern Section was established. Therefore the 25 counties in the household register of Lelang Commandery can be divided largely into the central region (18 counties), which have been marked as "kiho," and the frontier region of Yŏngdong (seven counties), where the

46 “唯不耐濊侯 至今猶置功曹主簿諸曹 皆濊民作之,” San Guo Zhi (三國志) 30, Records of Eastern Barbarians, "Tongokchŏ." 
commandant headquarters of the Eastern Section was established.

\section{Regional Distinctions according to the Household Register of Lelang Commandery}

In the studies published since Son Yŏngjong's paper, scholars have divided the 25 counties of Lelang Commandery into four regions. As mentioned earlier in this paper, Son asserted that seven counties from the seventh Taebang county to the 13th Hamja county were the seven counties of Daifang Commandery found in the "Treatise on Geography" in the Book of Jin, or in other words the region under the commandant headquarters of the Southern Section in Lelang Commandery during the Former Han, and distinguished the last seven counties from Tongi county as the seven Yŏngdong counties. Based on this grouping, the six counties (Chosŏn county to Tunyu county) and five counties (Susŏng county to T'anyŏl county) before and after the seven counties of Daifang Commandery (commandant headquarters of the Southern Section), were also grouped separately, so that all 25 counties were divided into four regions - Central Lelang, Southern Lelang, Northern Lelang, and seven Yŏngdong counties. This regional grouping has been widely accepted by many scholars to date. $^{47}$

It is curious, however, why the second district (Southern Lelang), where the commandant headquarters of the Southern Section was established, was recorded between the first (Central Lelang) and third (North-

47 Yun Yong-gu, "Nangnanggun Ch'ogiŭi Kunhyŏnjibaewa Hogu P'aak"; Lee Seongje, "Nangnangŭi Kunhyŏn Chaep'yŏn'gwa Ye"; Yoon Seon-Tae, "Hansagunŭi Yŏksajirijŏk Pyŏnch'ŏn'gwa 'Nangnanggun Ch'owŏn 4nyŏn Hyŏnbyŏl Hogubu' (Historical and Geographical Transformation of the Four Commanderies of the Han Dynasty and the 'Household Registers of Counties in Lelang Commandery in the Fourth Year of Chuyuan')," in Nangnanggun Hogubu Yŏn'gu (Studies on the Household Register of Lelang Commandery), Kwon Ojung et al. (Seoul: Tongbugayŏksajaedan, 2010). 
ern Lelang) districts. If the first and third districts were the central region of Lelang Commandery, the counties of the two districts would have been listed consecutively. This seems to imply that the second district was not under the rule of the commandant of the Southern Section but a central region similar in nature and character to the first and third districts.

Unlike the commandant headquarters of the Eastern Section, the establishment process of the commandant headquarters of the Southern Section is unclear. Based on the records of Tongokchŏ in the Records of the Three Kingdoms, the commandant headquarters of the Eastern Section is presumed to have been established in the Okchŏ region in the sixth year of Yuanfeng (75 BCE), during the reign of Emperor Zhao of Han, after Xiantu Commandery was invaded by the Yemaek people and was relocated to the northwestern region of Koguryo. ${ }^{48}$ In general, it has been surmised that the commandant headquarters of the Southern Section was established around the same time the Commandant of the Eastern Section was established.

However, the existence of the commandant headquarters of the Southern Section was only found in the section on Lelang Commandery in the "Treatise on Geography" from the Book of Han, which contains a record about Somyŏng county belonging to the commandant headquarters of the Southern Section. The names of commanderies and counties in the "Treatise on Geography" from the Book of Han are in accordance with the "list of counties affiliated to commanderies and states," created during the pe-

48 Lee Byung Do, "Nangnanggun'go (Lelang Commandery)," in Han'gukkodaesayŏn'gu (Seoul: Pagyŏngsa, 1976), 135. Based on the fact that Tongi county, which was the seat of Lintun Commandery, appears first on the list of the seven Yŏngdong counties, instead of Pullae county, which was the seat of the Commandant of the Eastern Section, some scholars believe that the commandant headquarters of the Eastern Section was not established in the fourth year of Chuyuan (45 BCE) (Lee Seongje, "Nangnangŭi Kunhyŏn Chaep'yŏn'gwa Ye," 221). However, since this speculation is based on the premise that the commandant headquarters were regional governing institutions with counties, similar to commanderies, it is necessary to reexamine this theory. 
riod in which the years changed from Yuanyan to Suihe in the reign of Emperor Cheng of Han ( 9 to $8 \mathrm{BCE}){ }^{49}$ Therefore it is clear that the commandant headquarters of the Southern Section was established, but it is difficult to know the exact time of its establishment. Considering the fact that the households in the Southern Section were recorded between the central regions (Central and Northern Lelang) in the household register of Lelang Commandery, it seems reasonable to assume that the commandant headquarters of the Southern Section was not in existence in the fourth year of Chuyuan (45 BCE), when the register was created.

The third district of Lelang Commandery, or the five counties in the Northern Lelang (Susŏng, Nubang, Honmi, P'aesu, and T'anyŏl) is sometimes understood to be the region of the Ye, or "Yŏngsŏye," which had occupied the area west of Nangrim Mountains. This region was incorporated into Lelang Commandery when Lintun Commandery was abolished and merged into Lelang in $82 \mathrm{BCE}^{50}$ According to this theory, the 25 counties in the household register of Lelang Commandery were organized into four groups: first group (Proto - six counties of Lelang Commandery), second group (seven counties that originally belonged to Zhenfan Commandery and later came to belong to Lelang), third group (five counties that originally belonged to the Yŏngsŏ region in Lintun Commandery and later came to belong to Lelang), and the fourth group (seven counties that originally belonged to Yŏngdong region in Lintun Commandery, later came to belong to Lelang, and was placed under the control of the commandant headquarters of the Eastern Section.

According to Maolingshu (茂陵書) compiled in the Han dynasty, ${ }^{51}$

49 Zhou Zhenhe, “西漢諸侯王國封域變遷考 (A study on the transformation of the territories of marquisates in Western Han)," in Xi Han Zhengqu Dili (Administrative Geography during the Western Han Dynasty) (Beijing: Renmin Chubanshe, 1987), 22-4.

50 Yoon Seon-Tae, 'Hansagunŭi Yŏksajirijŏk Pyŏnch'ŏn'gwa 'Nangnanggun Ch'owŏn 4nyŏn Hyŏnbyŏl Hogubu',” 251-2.

51 “[注] 臣瓚曰 茂陵書臨屯郡治東暆縣 去長安六千一百三十八里 十五縣 真番郡治霅 縣 去長安七千六百四十里 十五縣” Han Shu (Book of Han) 6, the third year of Yu- 
both the Zhenfan Commandery and Lintun Commandery consisted of fifteen counties each. It seems that only seven out of fifteen counties survived (the second district of Lelang) when the Zhenfan Commandery were incorporated into Lelang; and the same reasoning could be made for the five out of fifteen counties of Lintun Commandery that became part of Lelang (the third district). However, considering that Lelang Commandery did not undergo the process of integration and abolition as Zhenfan and Lintun commanderies did, it is questionable that only six counties (the first district) that originally belonged to Lelang Commandery survived.

The number of counties that originally belonged to Lelang Commandery is presumed to be close to 15, similar to that of Zhenfan and Lintun commanderies. Previous studies have claimed that among the 25 counties found in the "Treatise on Geography" from the Book of Han, seven counties each from Zhenfan and Lintun commanderies were transferred to Lelang when the former two commanderies were abolished and incorporated into the latter, while the rest (11 counties) originally belonged to Lelang Commandery. ${ }^{52}$

A close look at the list of counties found in the household register of Lelang Commandery reveals that it is difficult to find some semblance of an order in which they were arranged on the first and second tablets (the third tablet includes information on the seven counties of Yŏngdong). Among the 18 counties, there probably are counties that once belonged to Zhenfan and Lintun commanderies before they were incorporated into Lelang Commandery, but it is not easy to distinguish them. It is even more difficult to distinguish the regions in which the counties were located because it is possible that some of the counties were incorporated into Xiantu Commandery as well. In these circumstances, too many premises need to be met in order to assert that the 25 counties in the household register of Lelang Commandery can be divided into four regional sections.

anfeng, in the reign of Empere Wu.

52 Lee Byung Do, "Nangnanggun'go," 133-57. 
As of now, it makes most sense to divide the 25 counties in the household register of Lelang Commandery into two groups - the seven counties of Yŏngdong, which were separately inscribed on the third wooden tablet; and the 18 counties in the central regions of Lelang, inscribed on the first and second wooden tablets. This regional grouping scheme is also related to the nature of kiho discussed in the previous sections. The term kiho in the household register of Lelang Commandery refers to the 18 counties in the central regions of Lelang, excluding the Yŏngdong region.

The regional grouping of Lelang Commandery as seen in the household register is related to the multi-level ruling structure of the frontier counties. The frontier counties seem to have been governed under the multilevel ruling scheme involving both the governor and commandant. The frontier regions in the Han dynasty were equipped with elaborate defense systems, consisting of the commandant headquarters 都尉府 (commandants 都尉), companies 候官 (commanding officers of companies 候), $p u$ 部 (commanding officers/civil officials 候長/候史), and sections 燧 (heads of sections 燧長). The domicile of lower ranking officials who worked in defense facilities in the frontier regions was the nearest county, and the families of such lower ranking officials resided there as well. ${ }^{53}$ The soldiers in the frontier regions were supplied from all across the interior provinces within Han China, while lower ranking officers and government officials were usually local residents. ${ }^{54}$

Due to these circumstances, it is difficult to argue that the relationship between defense facilities and nearby counties had been strictly divided into the former overseeing military matters while the latter oversaw civil affairs. It is highly likely that both military and civil affairs were even

53 Momiyama Akira, “漢代エチナ=オアシスにおける開發と防衛線の展開 (The changes in the line of defense and the development of the Ejina-oasis region during the Han dynasty), " in 秦漢出土文字史料の研究 (A Study on the Historical Document Resources from the Qin and Han Dynasties) (Tokyo: Sobunsha, 2015), 263330.

54 Ichikawa, “前漢邊郡都尉考,” 10 . 
more closely linked particularly in the regions that were considered strategically important. Guanxian, which was discussed in the earlier section, could be such an example. Because of these regional characteristics, the frontier counties where commandant headquarters were installed had a multi-level structure - overseen by the governor of the commandery and governed by the commandant headquarters established in the region. As noted in the record, it might have been possible for guanxian in the Juyan area to receive direct orders from the governor and the commandant due to the multi-level governing scheme. It is likely that the frontier counties of the Yŏngdong region, where the commandant headquarters of the Eastern Section of Lelang Commandery was established, faced similar situations. Pullae county, the center of the commandant headquarters of the Eastern Section, was probably guanxian under the direct control of the commandant.

According to the "Treatise on Geography" from the Book of Han, there were yunzhang (雲鄣) in Lelang Commandery. Zhang (鄣 or 障) referred to fortresses built separately in the most dangerous parts of the frontier regions, where officials and soldiers were deployed to prevent invasions from foreign powers. In the wooden documents excavated from the frontier regions, zhang generally refers to companies (houguan), and the heads of companies (hou) were also called zhanghou. Moreover, soldiers assigned to companies were also called zhangzu. ${ }^{55}$

Yunzhang in Lelang Commandery could have been the head of a fortress related to companies (houguan), which were defense organizations in the peripheral regions. Records from Guangyun and Jiyun both state that there were zhayangbu (霅陽部) and zhayangzhang (霅陽障) in Lelang Commandery, which are considered to be military systems related to Hap county(霅縣), the center of Zhenfan Commandery. ${ }^{56}$ If zhayangzhang had

55 京都大學人文科學研究所簡牘研究班, 漢簡語彙: 中國古代木簡辭典, 277.

56 Yun Yong-gu, 'Nangnangjŏn'gi Kunhyŏnjibaeseryŏgŭi Chongjokkyet'onggwa Sŏnggyŏk (Ehnic Lineage and Characteristics of the Governing Powers of Commanderies and Counties prior to the time of Lelang Commandery)," Yoksa Hakpo 
been established in the commandant headquarters of the Southern Section, which had been the territory of Zhenfan Commandery, then similarly zhazhang could be military defense facilities established in the region under the control of the commandant headquarters of the Eastern Section.

The reason the commandant headquarters of the Eastern Section was newly established in Puri county (Pullae county) rather than in Tongi county, the center of Lintun Commandery, is probably because the region where Pullae county was located was more militarily important than Tongi county. Among the seven Yŏngdong counties in the household register of Lelang Commandery, the number of households in Puri County was the largest with 1,564 households and 12,348 residents. Also, the population increase was the highest with 401 new households over one year. Okchŏ (Pujo county) of Yŏngdong, in particular, had been invaded by the Yimaek(夷貃) in 75 BCE, which then prompted the relocation of the center of Xiantu Commandery in later years. The Yimaek are understood to be the people of proto-Koguryŏ, who were an indigenous, native people of Kojosŏn.

Yŏngdong was a region vulnerable to the invasion of Koguryŏ forces. Since the early years in the reign of King Taemushin (18-43 CE), Koguryŏ attacked the T'anyŏl county region in Lelang Commandery to secure a transportation route to advance into Tongokchŏ, and as a result the seven Yŏngdong counties were separated from Lelang Commandery after the abolishment of the commandant headquarters of the Eastern Section in 30 CE. In the fourth year in the reign of King T'aejo (56 CE), Koguryŏ conquered Tongokchŏ during its military operation to drive out Lelang forces from that region. ${ }^{57}$

The household register of Lelang Commandery was created 30 years after the invasion of the Yimaek (proto-Koguryŏ) in 75 BCE. It is highly

126 (1990): 19.

57 Lee Jong-Rok, “Koguryǒŭi Tongokchŏ Chŏngbŏlgwa Nangnanggun (The Lelang Commander and Koguryŏ's Conquest of Tongokchŏ)," Sŏnsawa Kodae (Prehistory and Ancient Times) 49 (2016): 55-6. 
possible Yŏngdong was a frontier region where Lelang forces and indigenous people were in conflict at the time. Therefore the establishment of the commandant headquarters of the Eastern Section could be understood in terms of the military situation faced by Lelang.

\section{Conclusion}

As examined in this paper, the household register of Lelang Commandery confirms that the number of households in the 18 main counties and in the seven Yŏngdong counties were calculated separately. The term kiho at the end of the household register was a term used to specify a certain number of households of the 18 main counties. This term implies that the 18 counties were under the governor's direct control, while the seven Yŏngdong counties were under the control of the commandant headquarters of the Eastern Section.

However, the fact that the households of all 25 counties, including the seven Yŏngdong counties, were included in the household register shows that the Yŏngdong region was also under the control of the governor of Lelang. In other words, the seven Yŏngdong counties were areas that were under the control of both the governor of Lelang and the commandant of the Eastern Section.

In previous studies, scholars have debated the central government's means to govern the seven Yorngdong counties: some argue that the ruling system of the seven counties had been centralized under the governor of Lelang, while others assert that the commandant of the Eastern Section ruled over them. However, an examination of the household register shows that a multi-level ruling structure had been implemented, in which the seven Yŏngdong counties were ruled by both the governor of Lelang and the commandant of the Eastern Section. 


\section{Reference}

1. Chen, Mengjia. “漢簡所見居延邊塞與防御組織 (Fortresses and defense organizations in the frontier region of Juyan as seen from Han dynasty wooden tablets)." Kao Gu Xue Bao (Acta Archaeologica Sinica) 1 (1964).

2. Ichikawa, Ninzo. “前漢邊郡都尉考 (Thoughts on the commandants of frontier commanderies of the Former Han)." Rissho Daigaku Kyoyobu Kiyo (Bulletin of the College of Education, Rissho University) 2 (1968): 1-13.

3. Kadoya, Tsuneko. “漢代居延における軍政系統と縣との關わりにつ いて(The relationship between the military system and counties in Juyan during the Han dynasty)." Shilin 76-1 (1993).

4. Kamada, Shigeo. “郡都尉 (Commandants of Commanderies).” In Shin Kan Seiji Seido no Kenkyu (Research on the Political System in the Qin and Han Dynasties). Tokyo: Nihon Gakujutsu Shinkōkai, 1962.

5. Kim, Kyung-Ho. “Chinhansigi Hogumunsǒwa Pyŏn'gyŏng Chibae (Household register documents and the rule over the frontier region in the Qin and Han dynasties).” In Nangnanggun Hogubu Yŏn'gu (Studies on the Household Register of Lelang Commandery), Kwon Ojung et al. Seoul: Tongbugayŏksajaedan, 2010.

6. Kim, Byung-joon. "Nangnanggun Ch'ogiŭi P'yŏnhogwajŏnggwa 'Hohanch'obyŏl': 'Nangnanggun Ch'owŏnsanyŏn Hyŏnbyŏrhogudaso $\square \square$ ' Mokkanŭl Tansŏro (The process of household registration in the early years of Lelang Commandery and the 'divide and rule' policy toward Hu and Han: using the wooden tablets on the increase and decrease of the number of households in Lelang Comandery by County in the fourth year of Chuyuan)." Mokkan'gwa Munja (Wooden Documents and Inscriptions Studies) 1 (2008): 139-86.

7. Kim, Byung-joon. “Chinhanjegugŭi Pyŏn'gyŏng Iminjok Chibaewa Pudowi (Commandants and the rule over ethnic groups in the frontier regions of the Jin-Han Dynasties.” In Chŏnt'ongsidae Tongasiaŭi 
Oegyowa Pyŏn'gyŏnggigu (Foreign Affairs and Institutions in the Frontier Regions of East Asia in the Ancient Times), edited by Tongbugayŏksajaedan. Seoul: Tongbugayŏksajaedan, 2013.

8. Kim, Byung-joon. "Nangnanggun Tongbudowi Chiyŏk Pyŏnhyŏn'gwa Kunhyŏnjibae (Frontier counties in the Commandant of the Eastern Section region of Lelang Commandery and the Governing of Counties and Commanderies)." Han'gukkotaesayón'gu (The Journal of Ancient Korean History) 78 (2015): 139-83.

9. Kim, Han Kyu. "Handae Pyŏn'gunch'ejeŭi Kujojŏk Sŏnggyŏk (The Structural Nature of the Frontier Commandery System)." In Kodaejunggukchŏksegyejilssŏyŏn'gu (A Study on the Ancient Chinese World Order). Seoul: Iljogak, 1982.

10. Kim, Jung-Bae. "Kojosŏnŭi Ch'ingwanggwa In'gu Munje (The Claiming of Kingship and the Issue of Population in Kojosŏn)." In Kojosŏne Taehan Saeroun Haesŏk (A New Interpretation of Kojosŏn). Seoul: Koryŏdaehakkyo Minjongmunhwayŏn'guwŏn, 2010.

11. Kwon, Ojung. Nangnanggun Yŏn'gu: Chungguk Kodaebyŏn'gune Taehan Saryejŏk Kŏmt'o (A Study on Lelang Commandery: Review of a Case of an Ancient Frontier Commander). Seoul: Iljogak, 1992.

12. Kwon, Ojung. "Handae Pyŏn'gunŭi Pudowi (Commandants of frontier commanderies in the Han dynasty)." Tongyangsahagyŏn'gu (A Study of the History of Asia) 88 (2004): 1-32.

13. Kwon, Ojung. "Nangnanggun Wangjojŏnggwŏn Sŏngnibŭi Kukchejŏk Hwan'gyŏng (The International Environment Surrounding the Dynastic Government of Lelang Commandery)." Yoksa Hakbo 196 (2007).

14. Kwon, Ojung. 'Nangnanggun Yŏn'guŭi Hyŏnhwanggwa Kwaje (Trends and Challenges of Research on Lelang Commandery)." In Nangnanggun Hogubu Yŏn'gu (Studies on the Household Register of Lelang Commandery), Kwon Ojung et al. Seoul: Tongbugayŏksajaedan, 2010.

15. Lee, Jong-Rok. "Koguryŏŭi Tongokchŏ Chŏngbŏlgwa Nangnanggun (The Lelang Commander and Koguryŏ's Conquest of Tongokchŏ).” 
Sŏnsawa Kodae (Prehistory and Ancient Times) 49 (2016): 37-66.

16. Lee, Seongje. "Nangnangŭi Kunhyŏn Chaep'yŏn'gwa Ye (Reorganization of Counties and Commanderies in Lelang and the Ye people)." In Nangnanggun Hogubu Yŏn'gu (Studies on the Household Register of Lelang Commandery), Kwon Ojung et al. Seoul: Tongbugayŏksajaedan, 2010.

17. Lee, Sung-Kyu. "Chungguk Kunhyŏnŭrosŏŭi Nangnang (Lelang as a Commander of China).” In Nangnangmunhwayŏn'gu (A Study of Nangnang Culture), Lee Sung-Kyu et al. Seoul: Tongbugayŏksajaedan, 2006.

18. Momiyama, Akira. “漢代エチナ=オアシスにおける開發と防衛線の展 開 (The changes in the line of defense and the development of the Ejina-oasis region during the Han dynasty).”In 秦漢出土文字史料の 研究 (A Study on the Historical Document Resources from the Qin and Han Dynasties). Tokyo: Sobunsha, 2015.

19. Noguchi, Yu. “前漢邊郡都尉府の職掌と邊郡統治制度 (The Duties of the Office of the Chief Commandant in the Border Regions and the System of Rule of the Border Regions)." Tôyôshi Kenkyû (The Journal of Oriental Research) 71-1 (2012): 1-35.

20. Son, Yŏngjong. "Rangnanggun Nambujiyŏk(Huŭi Taebanggun Chiyŏk)ŭi Wich'i: 'Rangnanggun Ch'owŏn 4nyŏn Hyŏnbyŏl Hogudaso $\square \square$ ' T'onggyejaryorŭl Chungsimŭro [The Location of the Southern Region of Lelang Commandery (later, the Region of Daifeng Commandery): Focusing on the Statistical Source of the Record of the Increase and Decrease in the Number of Households in Lelang Commandery by Country in the Fourth Year of Chuyuan]." Ryŏksagwahak (Historical Science) 198 (2006).

21. Son, Yŏngjong. "Ryodongjibang Chŏnhan Kunhyŏndŭrŭi Wich'iwa Kŭ Huŭi Pyŏnch'ŏn 1 (The locations of Former Han counties in Liaodong and changes afterwards 1)." Ryŏksagwahak (Historical Science) 199 (2006).

22. Son, Yŏngjong. Chosŏndandaesa: Koguryŏsa 1 (History of Korea: History of Koguryŏ 1). Pyongyang: Kwahakpaekkwasajŏnch'ul 
p'ansa, 2006.

23. Son, Yŏngjong. Chosŏndandaesa: Koguryŏsa 5 (History of Korea: History of Koguryŏ 5). Pyongyang: Kwahakpaekkwasajŏnch'ul p'ansa, 2008.

24. Yan Gengwang, Qin Han Difang Xingzheng Zhidu (Regional Administrative Systems in the Qin and Han Dynasties). Shanghai: Shanghai gu ji chu ban she, 2007 (Original Publication 1961).

25. Yun, Jae-Seug. "Chinhandae Hogubuwa Kŭ Unyong (Household Registers from the Qin and Han Dynasties and Their Management)." In Nangnanggun Hogubu Yŏn'gu (Studies on the Household Register of Lelang Commandery), Kwon Ojung et al. Seoul: Tongbugayŏksajaedan, 2010.

26. Yoon, Seon-Tae. "Hansagunŭi Yŏksajirijŏk Pyŏnch'ŏn'gwa 'Nangnanggun Ch'owŏn 4nyŏn Hyŏnbyŏl Hogubu' (Historical and Geographical Transformation of the Four Commanderies of the Han Dynasty and the 'Household Registers of Counties in Lelang Commandery in the Fourth Year of Chuyuan')." In Nangnanggun Hogubu Yŏn'gu (Studies on the Household Register of Lelang Commandery), Kwon Ojung et al. Seoul: Tongbugayŏksajaedan, 2010.

27. Yun, Yong-gu. 'Nangnangjŏn'gi Kunhyŏnjibaeseryŏgŭi Chongjokkyet'onggwa Sŏnggyŏk (Ethnic Lineage and Characteristics of the Governing Powers of Commanderies and Counties prior to the time of Lelang Commandery)." Yoksa Hakpo 126 (1990): 1-44.

28. Yun, Yong-gu. "Saero Palgyŏndoen Nangnang Mokkan: Nangnanggun Ch'owŏnsanyŏn Hyŏnbyŏrhogubu (Newly Discovered Wooden Tablets from Lelang: The Household Register of Lelang Commandery by county in the fourth year of Chuyuan)." Han'gukkotaesayŏn'gu (The Journal of Ancient Korean History) 46 (2007): 241-63.

29. Yun, Yong-gu. "P'yŏngyangch'ult'o 'Nangnanggun Ch'owŏnsanyŏn Hyŏnbyŏrhogubu' Yŏn'gu (The Household Register of Lelang Commandery by county in the fourth year of Chuyuan excavated from Pyongyang)." Mokkan'gwa Munja (Wooden Documents and 
Inscriptions Studies) 3 (2009): 273-310.

30. Yun, Yong-gu. "Nangnanggun Ch'ogiŭi Kunhyŏnjibaewa Hogu P'aak (The Rule over Commanderies and Counties and Household Census in the Early Years of Lelang Commandery)." In Nangnanggun Hogubu Yŏn'gu (Studies on the Household Register of Lelang Commandery), Kwon Ojung et al. Seoul: Tongbugayŏksajaedan, 2010.

31. Zang, Kehe (蔵克和) and Gui Rui (郭瑞). 中國異體字大系: 隷書篇 (An Overview of Variant Characters in Chinese: Lishu Calligraphy). Shanghai: Shanghai shu hua she, 2010.

32. Zhang, Chunlong, Song Shaohua and Zheng Shubin ed. Hu Xiang Jian Du Shu Fa Xuan Ji (Collection of Calligraphy on Bamboo and Wooden Tablets from Huxiang). Changsha: Hunan mei shu chu ban she, 2012.

33. Zhou, Zhenhe (周振鶴). “西漢諸侯王國封域變遷考 (A study on the transformation of the territories of marquisates in the Western Han)." In $X i$ Han Zhengqu Dili (Administrative Geography during the Western Han Dynasty). Beijing: Renmin Chubanshe, 1987. 
$<$ Abstract $>$

\section{A New Approach to the Household Register of Lelang Commandery}

Dae-Jae Park

The household register of Lelang Commandery first revealed in North Korea in 2006 is comprised of wooden tablets that contain detailed information on the number of households of 25 counties in Lelang Commandery. By exploring the nature of kiho (其戶), an item found at the end of the household register of Lelang Commandery, this study illustrates the fact that there were regional distinctions between the 18 counties of the central region and the seven counties of Yŏngdong. Kiho refers to the households in eighteen counties, of the total households in Lelang Commandery, excluding the seven counties of Yŏngdong. This demonstrates that the 18 counties in the central region had been under the direct control of the governor of Lelang, while the seven Yŏngong counties were under the jurisdiction of the commandant headquarters of the Eastern Section, an office that was established separately to govern the seven counties. At the same time, this article also notes that the number of households in all 25 counties of Lelang Commandery was recorded together on the document, as this meant that the administrative jurisdiction of the governor of Lelang included all 25 counties, including the seven Yŏngdong counties. Since the commandant headquarters of the Eastern Section were a military office under the command of the governor of Lelang Commandery, the seven Yŏngdong counties were also under the governor's administrative control. Therefore the seven Yŏngdong counties can be understood as a region governed indirectly by the governor of Lelang and directly by the commandant headquarters of the Eastern Section.

Keywords: Lelang Commandery (樂浪郡), household register (戶口簿), seven counties of Yŏngdong (嶺東 7縣), inner commandery (內郡), frontier commandery (邊郡), section commandants (部都尉), commandery commandant (郡都尉), governor of Lelang (樂浪太守), Commandant of the Eastern Section (東部都尉) 


\section{〈국문초록〉}

\section{낙랑군 호구부에 대한 새로운 접근}

박대재 (고려대 한국사학과 교수)

2006년 북한에서 처음 공개된 樂浪郡 戶口簿는 기원전 45 년 낙랑군 소속 25 개 縣의 현별 호구수를 상세히 기록한 集計 木簡이다. 이 글에서는 낙랑군 호구부 말 미에 기록된 ‘其戶'의 성격에 새롭게 접근함으로써, 낙랑군 25 개현 내에 本郡 18 현과 嶺東 7 현 사이의 지역구분이 있었다는 사실을 밝혀보았다. '其戶'는 낙랑군 전체 호구수(凡戶) 가운데 영동 7 현을 제외한 本郡 18 현의 호구수만 따로 집계한 것이다. 이것은 본군 18 현 지역이 太워가 직접 관할한 지역이며, 나머지 영동 7 현 은 별도로 설치된 東部都尉의 관할 아래에 있었던 지역이라는 사실을 시사해준다. 그러면서도 호구부에는 영동 7 현을 포함해 낙랑군 소속 25 개현의 호구수를 일괄 기록되어 있다는 점도 아울러 주목해 보았다. 이것은 樂浪太守의 행정 관할 범위 가 영동 7현 지역까지 모두 포괄한다는 것을 의미하는 것이다. 동부도위 역시 郡 太守의 통솔 하에 있던 郡官이라는 점에서, 영동 7현도 태수의 행정적 관할 범위 에 포함되어 있었던 것이다. 결국 영동 7현은 樂浪太守의 간접지배와 東部都尉의 직접지배가 중층적으로 시행되었던 지역이라고 이해할 수 있다.

주제어: 樂浪郡, 戶口簿, 嶺東 7縣, 內郡, 邊郡, 部都尉, 郡都尉, 樂浪太守, 東部 都尉 